\title{
Creating an Academic Program Focusing on Energy Management and Sustainability
}

\author{
Wes Grebski \\ The Pennsylvania State University, USA \\ Michalene Grebski \\ Northampton Community College, Monroe Campus, USA \\ Marek Profaska \\ Silesian University of Technology, Poland
}

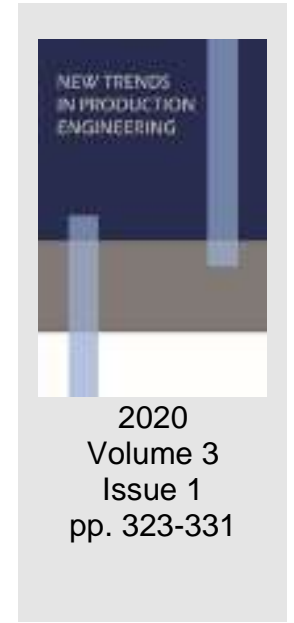

Date of submission to the Editor: 12/2019

Date of acceptance by the Editor: 01/2020

\section{INTRODUCTION}

The Alternative Energy and Power Generation Engineering Track (AE\&PGT) is an $A B E T$ accredited program, which will prepare graduates to enter the job market in the alternative and renewable energy sector as well as the power generation industry. ABET is nonprofit, ISO 9001 certified organization from USA, that accredits college and university programs in applied and natural science, computing, engineering and engineering technology (ABET). The graduates of AE\&PGT will have the critical knowledge and skills needed to begin their careers in this growing industry.

The learning environment is continuously changing for every level of education (Martínez-Medina and Arrebola, 2019; Saraiva et all, 2019). For example, emerging technologies referred to as 'Industry 4.0' or the 'fourth industrial revolution' have prompted many to develop student's socio-technical skills (Trevelyan, 2019). A new field of knowledge has emerged: sustainability science, which seeks to understand the fundamental nature of the interactions between nature and society (Sánchez-Carracedo et all, 2019; Salovaara, Soini and Pietikäine, 2019). The United Nations has attempt to implement strategies to achieve sustainable development. The 2030 agenda contains a set of 17 objectives - Sustainable Development Goals, which are to be achieved by the year 2030. Sustainability science must be profoundly interdisciplinary and transdisciplinary in order to be able to tackle complex challenges (SánchezCarracedo et all, 2019). Tejedor et all (2019) highlight that "higher education is a principal agent for addressing the sustainable development goals proposed by the 2030 Agenda, because of its key mission of knowledge generation, teaching and social innovation for sustainability". Vargas et all's (2019) research results suggested that policy frameworks should include "collaboration, partnership, education, outreach, teaching and learning, staff development, curriculum review, research, campus operations and policy" that can support sustainable development implementation. It requires e.g. developing the field of 
management, research and development, teacher evaluation and also changing academic programs (Tejedor et all, 2019; Weng, Liu and Chuang, 2019).

The power generation industry is deeply concerned with the lack of a qualified workforce in the future. There is an emerging need for multidisciplinary quality engineers with broad range skills capable to design, develop, and integrate new technologies applied to the alternative and renewable energy technology industry.

At the same time, the government is placing mandates on the amount of power which will need to be generated by renewable energy sources. These mandates are constantly increasing the percentage of power which must come from alternative clean energy.

The current workforce in the power generation industry has not been trained in the alternative renewable energy field. Training in this area is critical if we are to satisfy the demand for skilled workers in the energy and power sector. The graduates from the proposed program will have extensive training in the alternative and renewable energy fields. They will also have a critical understanding of the environmental, social and economic aspects of the power generation industry. The program's goal is to create graduates who will immediately enter the job market in the alternative energy and/or power generation industry. They will have the background, knowledge, and skills necessary to be successful in the contemporary power generation sector while being able to lead the industry toward a more environment-friendly goal, using alternative and renewable energy technologies (Buchanan and Bostwick, 1995; Dudeck and Grebski, 2008; Ferrara and Vavreck, 2003; Frenzel and Louis, 2003).

The aim of this chapter is presentation of the process for developing a new engineering program specializing in sustainable energy and power generation: Alternative Energy and Power Generation Engineering Track (AE\&PGT). Desk research method is used. Publication is based $A B E T$ requirement.

\section{PROGRAM EDUCATIONAL OBJECTIVES}

The newly implemented Engineering program with an AE\&PGT provides students with a broad foundation in engineering specializing in alternative energy and power generation. The program provides opportunities for industryuniversity cooperation to support student research and design projects. Graduates from the AE\&PGT are prepared for careers in for-profit or nonprofit organizations, or to further their education in graduate school.

The educational objectives of this Engineering program are to produce graduates who, during the first few years of professional practice, will:

- Be employed by industry or government in the fields, such as design, research and development, experimentation and testing, manufacturing, and technical sales.

- Assume an increasing level of responsibility and leadership within their respective organizations. 
- Communicate effectively and work collaboratively in multidisciplinary and multicultural work environments.

- Recognize and understand global, environmental, social and ethical contexts of their work.

- Progress to advanced degree and certificate programs and be committed to lifelong learning to enhance their careers and be able to provide flexibility in responding to changing social and technical environments.

Graduates from the program will have a strong foundation in engineering with a focus on energy sources commonly used to supply utility power using alternative approaches, such as nuclear, solar and wind to supplement or replace traditional coal and gas power. The program provides opportunities for industry-university cooperation to support student research and design projects, thus preparing graduates for careers in for-profit or nonprofit organizations, or to further their education in graduate school. The program faculty works closely with industry partners to provide students with opportunities to work with faculty on relevant design or research projects.

\section{PROGRAM EDUCATIONAL OUTCOMES}

To support program educational objectives, the following program outcomes were established. At the time of graduation, the students in the program must be able to demonstrate the following objectives.

- Ability to apply knowledge of mathematics, science and engineering.

- Ability to design and conduct experiments.

- Ability to analyze and interpret data.

- Ability to design a system, component or process to meet the desired needs within realistic constraints, such as economic, environmental, social, political ethical, health and safety, manufacturability and sustainability.

- Ability to function in multidisciplinary teams.

- Ability to identify, formulate and solve engineering problems.

- Understand professional and ethical responsibility.

- Ability to communicate in oral and written forms.

- Understand the impact of engineering solutions in a global, economic, environmental and societal context.

- Recognize the need for lifelong learning.

- Engage in lifelong learning.

- Be aware of contemporary issues.

- Ability to use the techniques, skills and modern engineering tools necessary for engineering practice.

The attainment of student educational outcomes prepares graduates to meet the program educational objectives. Based on the student outcomes, the faculty from the AE\&PGT program developed the course content and requirements. 


\section{PROGRAM REQUIREMENTS}

The proposed Engineering curriculum is comprised of five different categories of courses.

- General Education - 31 credits

- Basic Mathematics and Science - 35 credits

- Engineering Fundamentals - 12 credits

- Design Component - 11 credits

- Track Courses/Professional Focus - 38 credits

The total credits needed for graduation is 127 . It should also be noted that 15 credits from Basic Mathematics and Science also count towards Pennsylvania State University (USA) 46 credit general education requirement.

In the United States, the higher education system credits are calculated differently than credit hours calculated in the European higher education system. The specific category breakdown of the required courses is shown below in Table 1. The prerequisite flow chart is shown in Table 2. The courses in red are the track specific courses. A semester-by-semester course planner is shown in Table 3.

\section{General Education ( $31 / 46$ credits) \\ Speaking and Writing \\ Health and Physical Activity \\ Natural Sciences \\ Arts \\ Humanities \\ Social Sciences \\ First Year Seminar}

\section{Basic Math and Science ( 35 credits)}

Calculus/Differential Equations

Chemistry (Lecture and Laboratory)

Physics (Lecture and Laboratory)

\author{
Engineering Fundamentals \\ (12 credits) \\ Statics \\ Computation and Modern Methods \\ Strength of Materials \\ Thermodynamics
}

\section{Design Component (11 credits)}

Computer Aided

Design/Drafting/Modeling

Capstone Design Project

Track Courses/Professional Focus

(38 credits)

Detailed below

Table 1 Specific track courses for Alternative Energy and Power Generation Track

\begin{tabular}{|l|l|c|}
\hline \multicolumn{1}{|c|}{ Course } & \multicolumn{1}{c|}{ Name } & Credit \\
\hline EE 210 & Circuits and Devices & 4 \\
\hline EME 303 & Fluid Mechanics in Energy & 3 \\
\hline EE 314 & Signals and Circuits II & 3 \\
\hline EE 485 & Energy Systems and Conversion & 3 \\
\hline EE 488 & Power System Analysis I & 3 \\
\hline EGEE 302 & Principles of Energy Engineering & 3 \\
\hline EGEE 420 & Hydrogen and Fuel Cells & 3 \\
\hline EGEE 437 & Fundamentals of Renewable Energy & 3 \\
\hline EGEE 438 & Sustainable Energy Options & 3 \\
\hline EGEE 441 & Electrochemical Energy Conversion & 3 \\
\hline ME 345 & Instrumentation, Measurement and Statistics & 4 \\
\hline NUCE 401 & Introduction to Nuclear Engineering & 3 \\
\hline
\end{tabular}


Table 2 Prerequisite flow chart for Alternative Energy and Power Generation Track.

(Red blocks are energy-related courses)

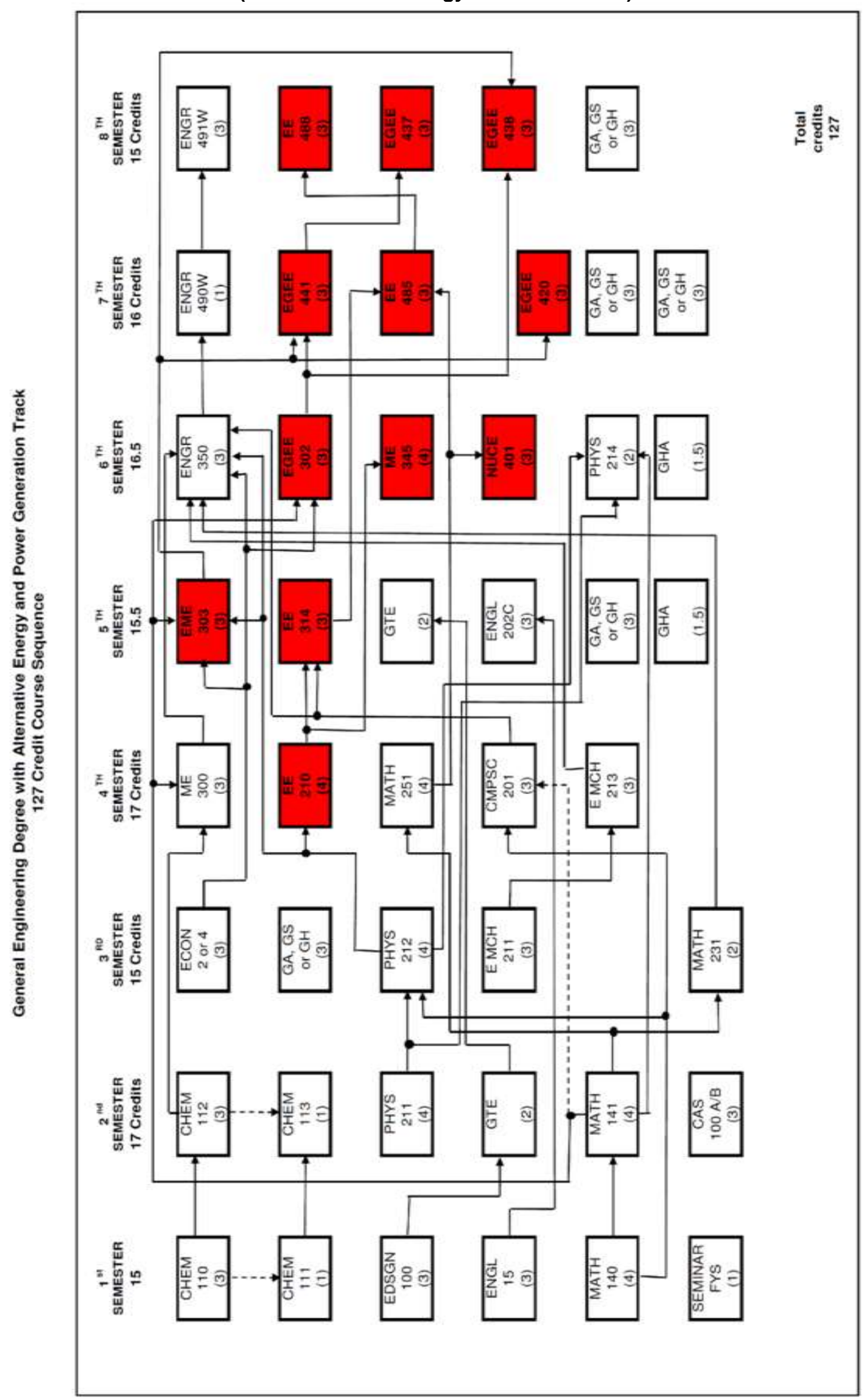


Table 3 Recommended course planner for Bachelor of Science in Engineering (Alternative Energy and Power Generation Track)

\begin{tabular}{|c|c|c|c|c|c|}
\hline \multicolumn{3}{|c|}{$1^{\text {st }}$ Semester } & \multicolumn{3}{|c|}{$2^{\text {nd }}$ Semester } \\
\hline Course & Name & Credit & Course & Name & Credit \\
\hline $\begin{array}{l}+ \text { CHEM } \\
110\end{array}$ & Chemical Principles & 3 & $\begin{array}{l}\text { CAS } \\
100 \mathrm{~A} / \mathrm{B}\end{array}$ & Effective Speech & 3 \\
\hline $\begin{array}{l}\text { CHEM } \\
111 \\
\end{array}$ & Experimental Principles & 1 & $\begin{array}{l}\text { CHEM } \\
112 \\
\end{array}$ & Chemical Principles & 3 \\
\hline $\begin{array}{l}\text { EDSGN } \\
100\end{array}$ & Engineering Design & 3 & $\begin{array}{l}\text { CHEM } \\
113\end{array}$ & Experimental Chemistry & 1 \\
\hline $\begin{array}{l}\text { ENGL } \\
15\end{array}$ & Rhet. \& Comp & 3 & A GTE & General Tech Elective & 2 \\
\hline FYS & First Year Seminar & 1 & $\begin{array}{l}+ \text { MATH } \\
141\end{array}$ & Calculus II & 4 \\
\hline $\begin{array}{l}+ \text { MATH } \\
140\end{array}$ & Calculus I & 4 & $\begin{array}{l}+ \text { PHYS } \\
211\end{array}$ & Mechanics & 4 \\
\hline & sum & 15 & & sum & 17 \\
\hline \multicolumn{3}{|c|}{$3^{\text {rd }}$ Semester } & \multicolumn{3}{|c|}{$4^{\text {th }}$ Semester } \\
\hline $\begin{array}{l}\text { ECON } 2 \\
\text { OR } 4\end{array}$ & Economics $(\mathrm{GH})$ & 3 & $\begin{array}{l}\text { CMPSC } \\
201\end{array}$ & Programming in $\mathrm{C}_{++}$ & 3 \\
\hline $\begin{array}{l}++\mathrm{E} \\
\mathrm{MCH} 211\end{array}$ & Statics & 3 & $\begin{array}{l}+E E \\
210\end{array}$ & Circuits \& Devices & 4 \\
\hline $\begin{array}{l}\text { GA, GH } \\
\text { or GS }\end{array}$ & AHS Elective & 3 & $\begin{array}{l}\text { MATH } \\
251\end{array}$ & Ordinary Diff. Equations & 4 \\
\hline $\begin{array}{l}\text { MATH } \\
231\end{array}$ & $\begin{array}{l}\text { Calc. of Several } \\
\text { Variables }\end{array}$ & 2 & $\begin{array}{l}+ \text { ME300 } \\
\text { or } \\
\text { EME301 }\end{array}$ & Thermodynamics & 3 \\
\hline $\begin{array}{l}\text { PHYS } \\
212\end{array}$ & Electricity \& Magnetism & 4 & $\begin{array}{l}\mathrm{E} \mathrm{MCH} \\
213\end{array}$ & Strength of Materials & 3 \\
\hline & sum & 15 & & sum & 17 \\
\hline \multicolumn{3}{|c|}{$5^{\text {th }}$ Semester } & \multicolumn{3}{|c|}{$6^{\text {th }}$ Semester } \\
\hline E E 314 & Signals \& Circuits II & 3 & $\begin{array}{l}\text { EGEE } \\
302\end{array}$ & $\begin{array}{l}\text { Principles of Energy } \\
\text { Engr. }\end{array}$ & 3 \\
\hline $\begin{array}{l}\text { EME } \\
303\end{array}$ & Fluid Mech. in Energy & 3 & $\begin{array}{l}\text { +ENGR } \\
350\end{array}$ & Comp. \& Mod. Meth. & 3 \\
\hline $\begin{array}{l}\text { ENGL } \\
202 C\end{array}$ & Technical Writing & 3 & GHA & $\begin{array}{l}\text { Health \& Physical } \\
\text { Activity }\end{array}$ & 1.5 \\
\hline $\begin{array}{l}\mathrm{GA}, \mathrm{GH}, \\
\text { or GS }\end{array}$ & AHS Elective & 3 & +ME345 & $\begin{array}{l}\text { Inst., Meas. \& } \\
\text { Statistics }\end{array}$ & 4 \\
\hline GHA & $\begin{array}{l}\text { Health \& Physical } \\
\text { Activity }\end{array}$ & 1.5 & $\begin{array}{l}\text { NUC E } \\
401\end{array}$ & Intro to Nuclear Engr & 3 \\
\hline A GTE & General Tech Elective & 2 & $\begin{array}{l}\text { PHYS } \\
214\end{array}$ & $\begin{array}{l}\text { Waves \& Quantum } \\
\text { Physics }\end{array}$ & 2 \\
\hline & sum & 15.5 & & & 16.5 \\
\hline \multicolumn{3}{|c|}{$7^{\text {th }}$ Semester } & \multicolumn{3}{|c|}{$8^{\text {th }}$ Semester } \\
\hline E E 485 & $\begin{array}{l}\text { Energy Systems } \\
\text { and Conv. }\end{array}$ & 3 & E E 488 & $\begin{array}{l}\text { Power System Analysis } \\
\text { I }\end{array}$ & 3 \\
\hline $\begin{array}{l}\text { EGEE } \\
420 \\
\end{array}$ & $\begin{array}{l}\text { Hydrogen } \\
\text { and Fuel Cells }\end{array}$ & 3 & $\begin{array}{l}\text { EGEE } \\
437 \\
\end{array}$ & $\begin{array}{l}\text { Fund. of Renew. } \\
\text { Energy }\end{array}$ & 3 \\
\hline $\begin{array}{l}\text { EGEE } \\
441\end{array}$ & $\begin{array}{l}\text { Electrochem. Energy } \\
\text { Conv. }\end{array}$ & 3 & $\begin{array}{l}\text { EGEE } \\
438\end{array}$ & $\begin{array}{l}\text { Sustain. Energy } \\
\text { Options }\end{array}$ & 3 \\
\hline $\begin{array}{l}\text { ENGR } \\
490 W\end{array}$ & Senior Design I & 1 & $\begin{array}{l}\text { ENGR } \\
491 W\end{array}$ & Senior Design II & 3 \\
\hline $\begin{array}{l}\text { GA, GH, } \\
\text { or GS }\end{array}$ & AHS Elective & 3 & $\begin{array}{l}\mathrm{GA}, \mathrm{GH} \text {, } \\
\text { or GS }\end{array}$ & AHS Elective & 3 \\
\hline $\begin{array}{l}\mathrm{GA}, \mathrm{GH}, \\
\text { or GS }\end{array}$ & AHS Elective & 3 & & & \\
\hline & sum & 16 & & sum & 15 \\
\hline
\end{tabular}




\section{Total Credits - 127}

+ Courses listed in boldface type require a grade of a $\mathrm{C}$ or better for graduation in this major

A General Technical Electives are 4 credits of engineering, science or mathematics at a similar or higher level required for the major. Choose from: BIOL 141 GN(3), BIOL 142(1), CHEM 202(3) or CHEM 210(3), CMPEN 270(4), CMPEN 271(3), CMPEN 275(1), EDSGN 110(2), EDSGN 210(2), E MCH 212(3) (Alternative Energy and Power Distribution Track only), E MCH 315(2), E MCH 316(1), MATH 220 GQ(2-3), MATH 232(2), MATH 310(3), and PHYS $213 \mathrm{GN}(2)$. Other GTE credits will be considered through the petition process.

\section{CONCLUSIONS}

The learning environment is continuously changing. Nowadays, higher education is being significantly shaped by the global sustainability agenda (Franco et all, 2018). Franco et all (2018) highlights that higher education institutions are "responsible for equipping the next generation of sustainability leaders with knowledge and essential skills". There is very important to understand by students the impact of engineering solutions in a global, economic, environmental, and societal context (Mota-Valtierra, RodríguezReséndiz and Herrera-Ruiz, 2019; Sundermann and Fisfer, 2019). This requires a constant revision of the teaching methodology and analysis of the curriculum (Gulikers, Brinkman and Runhaar, 2019; Waterman, Goldsmith, and Pasquale, 2019).

Higher education is a crucial sector for transfer of knowledge, innovation. The education process and the graduates' integration on the labor market are important for regional economic development and to contribute to building national and regional innovation systems (Epure, 2017; Rampersad, 2015). Chapter describes the development and implementation of the AE\&PGT program. The present focus of the engineering faculty and campus administration is to rapidly build an ecosystem for the new degree. The creation of the ecosystem is being done for the purpose of shortening the implementation cycle and allowing the program to mature, as well as allowing the program to remain relevant to the marketplace in Northeastern Pennsylvania (Dudeck and Grebski, 2008; Ferrara and Vavreck, 2003; Frenzel and Louis, 2003). Key partners of the ecosystem have been identified and mutually beneficial partnerships are being established.

\section{REFERENCES}

ABET, https://www.abet.org/ (Accessed: 17 December 2019).

Buchanan, W. and Bostwick, W. (1995) 'Managing Declining Enrollments in Engineering and Technology, American Society for Engineering Education', (ASEE) Annual Conference Proceedings, 2, pp. 2628-2631.

Dudeck, K. and Grebski, W. (2008) 'A New Vision for Engineering Technology Programs to Strengthen Recruitment and Retention', Proceedings of American Society for Engineering Education (ASEE), Annual Conference. 
Epure, M. (2017) 'University-business cooperation: adapting the curriculum and educational package to labor market requirements', Proceedings of the International Conference on Business Excellence, 11(1), pp. 339-349.

Ferrara, I. and Vavreck, A. (2008) 'Meeting Enrollment Challenges in Engineering Technology at Penn State Altoona', Proceedings of American Society for Engineering Education (ASEE), Annual Conference.

Franco, I., Saito, O., Vaughter, P., Whereat, J., Kanie, N. and Takemoto, K. (2018) 'Higher education for sustainable development: actioning the global goals in policy, curriculum and practice', Sustainability Science, 14(6), pp. 1621-1642.

Frenzel Jr., L. (2003) 'The Disappearing Associate Degree Program in Electronics Technology', American Society for Engineering Education, (ASEE) Annual Conference Proceedings, pp. 1439-1448.

Gulikers, J., Brinkman, D. and Runhaar, P. (2019) 'Using a rubric to grasp intercultural competence development in vocational education', Journal of Vocational Education \& Training, pp. 1-24.

Martínez-Medina, R. and Arrebola, J.C. (2019) 'Analysis of Sustainability Activities in Spanish Elementary Education Textbooks', Sustainability, 1, pp. 1-14.

Mota-Valtierra, G., Rodríguez-Reséndiz, J. and Herrera-Ruiz, G. (2019) 'Constructivism-Based Methodology for Teaching Artificial Intelligence Topics Focused on Sustainable Development', Sustainability, 11, pp. 1-18.

Rampersad, G.C. (2015) 'Developing University-Business Cooperation Through WorkIntegrated Learning', International Journal of Technology Management, 68(3-4), pp. 203-227.

Salovaara, J.J., Soini, K. and Pietikäine, J. (2019) 'Sustainability science in education: analysis of master's programmes' curricula', Sustainability Science, p1-15.

Sánchez-Carracedo, F., Moreno-Pino, F.M., Sureda, B., Antúnez, M. and Gutiérrez, I. (2019) 'A Methodology to Analyze the Presence of Sustainability in Engineering Curricula. Case of Study: Ten Spanish Engineering Degree Curricula', Sustainability, 11, pp. 1-27.

Saraiva, T.S., Almeida, M., Bragança, L. and Barbosa, M.T. (2019) 'Verification of the Adequacy of the Portuguese Sustainability Assessment Tool of High School Buildings, SAHSBPT, to the Francisco de Holanda High School, Guimarães', Sustainability, 1, pp. 1-21.

Sundermann, A. and Fisher, D. (2019) 'How Does Sustainability Become Professionally Relevant? Exploring the Role of Sustainability Conceptions in First Year Students', Sustainability,11, pp. 1-22.

Tejedor, G., Segalàs, J., Barrón, Á., Fernández-Morilla M., Teresa Fuertes, M., RuizMorales, J., Gutiérrez, I., García-González, E., Aramburuzabala, P. and Hernández À. (2019) 'Didactic Strategies to Promote Competencies in Sustainability', Sustainability, 11, pp. 2-24.

Trevelyan, J. (2019) 'Transitioning to engineering practice', European Journal of Engineering Education, 44(6), pp. 821-837.

Vargas, V.R., Lawthom, R., Prowse, A., Randles, S. and Tzoulas, K.: 'Implications of Vertical Policy Integration for Sustainable Development Implementation in Higher Education Institutions', Journal of Cleaner Production, 235(20), pp. 733-740.

Waterman, K.P., Goldsmith, L. and Pasquale, M. (2019) 'Integrating Computational Thinking into Elementary Science Curriculum: An Examination of Activities that Support Students' Computational Thinking in the Service of Disciplinary Learning', Journal of Science Education and Technology, pp. 1-12.

Weng, S-S., Liu, Y. and Chuang, Y-C. (2019) 'Reform of Chinese Universities in the Context of Sustainable Development: Teacher Evaluation and Improvement Based on Hybrid Multiple Criteria Decision-Making Model', Sustainability, 11, pp. 1-23. 


\section{Abstract.}

The chapter describes the process for developing a new engineering program specializing in sustainable energy and power generation: Alternative Energy and Power Generation Engineering Track. The graduates of described program will have the critical knowledge and skills needed to begin their careers in nowadays industry shaped by the global sustainability Agenda 2030. Engineers should focus on economic, social and environmental aspects of their work. Desk research method is used. Chapter is based ABET requirement (USA). Program educational objectives were developed based on the needs on industry and in close cooperation with industry. Chapter is also focusing on the development of the program outcomes as well as the curricular content. Program requirements, specific track courses and recommended course planner are provided. Some suggestions and recommendation are also included.

Keywords: Academic program, engineering curriculum, sustainability 